\title{
Determination of Criteria and Drought Tolerance of Prope-Legitimate Cocoa Seed Through Polyethylene Glycol Induction
}

\author{
Maera Zasari ${ }^{1}$, Agung Wahyu Susilo ${ }^{2)}$, Ade Wachjar ${ }^{3)}$, and Sudarsono ${ }^{3 *}$ \\ ${ }^{1)}$ Agrotechnology Study Program, Faculty of Agricultural, Fisheries and Biotechnology, bangka Belitung University, \\ Jl. Raya Balun Ijuk, Bangka, Kepulauan Bangka Belitung, Indonesia \\ ${ }^{2)}$ Indonesian Coffee and Cocoa Research Institute, Jl. PB. Sudirman 90 Jember 68118, East Java, Indonesia \\ ${ }^{3}$ Department of Agronomy and Horticulture, Faculty of Agriculture, Bogor Agricultural University, \\ Meranti Street, IPB Darmaga Campus, Bogor 16680, Indonesia

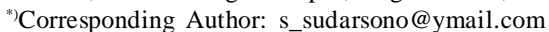 \\ Received: 24 February 2020 / Accepted: 27 March 2020
}

\begin{abstract}
The availability of drought tolerant rootstock becomes one of solution to obtain tolerant cocoa clone at drought condition. The production of rootstock is easier and faster by using prope-legitimate seeds as plant materials. Seed germination selection phase can accelerate the obtainment of tolerant cocoa rootstocks. The tolerance trait of prope-legitimate seeds can be determined by seed germination on media induced by polyethylene glycol (PEG) solution. To determine the tolerant seeds, it is effective by using a specific character as selection criteria. This study aimed to obtain criteria and selection character to determine drought tolerant characteristic of prope-legitimate seed through PEG 6000 induction in the germination phase. The research was conducted at the Agronomy Laboratory of the Indonesian Coffee and Cocoa Research Institute, Jember, East Java, Indonesia, used split plot design with five replications as experimental design. The main plot was solution of $0 \%$ and $6 \%$ PEG 6000, while the subplot were prope-legitimate seeds of 13 cocoa clones. The result showed that germination ability and sprout fresh weight were suitable as selection criteria to determine tolerant characteristic of prope-legitimate seeds to drought stress. Based on the value of stress susceptible index and clustering analysis, the tested prope-legitimate seeds were divided into three groups. The group of tolerant genotype consisted of Sca 06, while the group of medium tolerant were ICCRI 03, Sulawesi 02, KW 641, TSH 858, KEE 02, Sulawesi 03, and KW 617. The susceptible group consisted of six genotypes, namely ICS 60, KKM 22, KW 516, Sulawesi 01, and MCC 02.
\end{abstract}

Keywords: Cocoa, prope-legitimate seed, selection criteria, drought tolerance, PEG

\section{INTRODUCTION}

Cocoa is a very susceptible plant to drought stress (Amos \& Thompson, 2015; Gateau-Rey et al., 2018). Drought affects cocoa seedling mortality, decreases the fruit and seeds size and weight, and increases damage due to pest and disease attacks (Ofori et al., 2015). Drought threatens the future of cocoa production, therefore drought- tolerant cocoa clone are needed to solve the problems caused by drought (Cazares et al., 2010).

Efforts to obtain drought-tolerant cocoa plants have been carried out by Dos Santos et al. (2016); De Almeida et al. (2016); Setyawan et al. (2018); Zakariyya \& Indradewa (2018) through seed selection using the method of limiting water input to 
growing media. Selection is more difficult and less efficient when the number of seedlings is large enough on a large area (Alban et al., 2015; Dos Santos et al., 2016). The earlyphase screening technique for growth is highly prospective for obtaining droughttolerant species (Boopathi et al., 2013). Seed germination phase selection is conducted to obtain drought-tolerant plants easily, quickly, and accurately and can potentially grow well in the drought stress area (Petrovic et al., 2016).

The production of tolerant cocoa seedlings under dry growing conditions can also be done through a continuous technique approach using tolerant rootstock. This method is very prospective related to the role of the rootstock which is directly related to water conditions, nutrition, and various biotic and abiotic stresses in the growing environment (Susilo et al., 2005; Warschefsky et al., 2016). Cocoa rootstocks are usually obtained from multiplication of seeds from controlled crosses, but prope-legitimate seeds are more likely to be used as sources of rootstock propagation material (Susilo, 2015). Propelegitimate seeds are obtained from a female parent whose the identity is known with certainty that receives random pollen from other clones that grow close together in the parent garden. This seed can be used as propagation material to obtain tolerant rootstock.

Seed tolerance can be studied by germinating seeds on a homogeneous water deficit medium in a laboratory or greenhouse (Baloch et al., 2012). Water stress control carried out by using polyethylene glycol (PEG) solution induction is considered to be able to present the homogeneity of selection pressure (Khodarahmpour, 2011; George et al., 2013; Muscolo et al., 2014). Osmotic stress due to PEG 6000 is considered to able to stimulate equivalent drought conditions in the field. In the field capacity condition, the soil is considered to have an osmotic potential of around -0.33 bar while at the permanent wilting point reaches -15 bar (Mirbahar et al., 2013). PEG 6000 at concentrations of 5-20\% produces osmotic potentials ranging from -0.3 bar to -6.7 bar (Michel \& Kaufman, 1973; Mexal et al., 1975), therefore, they are often used for seed selection (Shao et al., 2015). PEG treatment on cocoa seeds has been carried out by Rahayu et al. (2014) and Hutabarat et al. (2018) which uses PEG to maintain seed quality. According to Rahardjo (1986), PEG was used to maintain the viability of cocoa seeds during seed storage and delivery.

Testing the tolerance of prope-legitimate against drought have not been studied. To estimate the genetic potential of tolerant prope-legitimate seeds requires selection criteria based on the genetic variability, heritability (Mayo, 1980), and correlation, that refer to the seed germination character in dry germination media (Sevik \& Ertruk, 2015; Widyastuti et al., 2016; Akbar et al., 2018). Drought tolerance could be determined based on the drought susceptibility index (Fischer \& Maurer, 1978), there is still limited studies regarding this issue. This study aimed to determine the tolerance properties of propelegitimate seeds to drought stress through induction of PEG solution.

\section{MATERIALS AND METHODS}

The study was conducted at the Agronomy Laboratory of the Indonesian Coffee and Cocoa Research Institute, Jember, East Java, Indonesia in November-December 2018. The temperature and humidity of the germination chamber during the study were recorded at about $29.8^{\circ} \mathrm{C}$ and $80.2 \%$, respectively. The genetic material used were prope-legitimate seeds from bulk cocoa clones consisting of KW 516, KW 617, KW 641, ICCRI 03, TSH 858, Scavina 06, KEE 02, KKM 22, 
MCC 02, ICS 60, Sulawesi 01, Sulawesi 02, and Sulawesi 03. The genetic material is a superior germplasm collection from the Indonesian Coffee and Cocoa Research Institute, Jember, Indonesia which has the potential to be developed as a drought tolerant rootstock.

The experiment was carried out using a randomized complete design. PEG 6000 solution (6\% and without PEG) induction treatment was the main plot and propelegitimate seed was a subplot. Determination of $6 \%$ PEG 6000 concentration was based on a preliminary experiment using random prope-legitimate seeds. The treatment was applied in 5 replications and in each treatment unit 25 seeds were sown on filter paper in a $(30 \times 20 \times 15) \mathrm{cm}^{3}$ sized box. The seedling media was moistened with $40 \mathrm{~mL}$ of the treatment solution then $20 \mathrm{~mL}$ solution was added every 2 days until the seeds were 14 days old. In the next step, PEG solution was applied as much as $40 \mathrm{~mL}$ until the germination was 21 days old.

Seed tolerance evaluation was carried out until the $21^{\text {st }}$ day by observing several components. These components were germination ability (\%) that was calculated based on the number of normal germinated seeds characterized by the appearance of two leaves in the $14^{\text {th }}$ and $21^{\text {st }}$ days; vigor index (\%) that was calculated based on the number of normal germinated seeds characterized by the appearance of two leaves on the $14^{\text {th }}$ day; seed growth potential (\%) that was calculated based on the number of seeds germinated on the $14^{\text {th }}$ and $21^{\text {st }}$ days. The number of sprouted leaves was measured on $21^{\text {st }}$ day; root length $(\mathrm{cm})$ was measured from base to root tip on $21^{\text {st }}$ day; shoot length $(\mathrm{cm})$ is measured from the base to the tip of the shoot on $21^{\text {st }}$ day; root/shoot ratio; fresh weight of the sprout/dry sprout $(\mathrm{g})$ was measured by weighing the sprout wet/ dry weight without cotyledon on $21^{\text {st }}$ days.
Data were analyzed to obtain the average value and standard deviation. Homogeneity variance was tested using the F-test at $\alpha 5 \%$ confidence level using $\mathrm{R}$ software version 3.44. Relative decrease and heritability were calculated as done by Susilo et al. (2005); also for genetic variability (Anderson \& Bancroft, 1952); and phenotype correlation (Singh \& Chaudhary, 1979). Genotype tolerance was determined using stress susceptibility index (Fischer \& Maurer, 1978). The stress susceptibility index was calculated by the formula: SSI $=(1-\mathrm{Ys} / \mathrm{Yp}) /(1-\overline{\mathrm{Y}} \mathrm{s} / \overline{\mathrm{Y}} \mathrm{p})$ (Fisher $\&$ Maurer, 1978), Ys = average specific genotype on drought stress conditions, Yp $=$ average specific genotype on optimum condition, $\overline{\mathrm{Y}} \mathrm{s}=$ average of all genotypes on drought stress and $\overline{\mathrm{Y}} \mathrm{p}=$ average of all genotypes on optimum condition. The grouping of seed genotypes was performed by using a heatmap clustergram analysis.

\section{RESULTS AND DISCUSSION}

\section{Selection Criteria}

Seed selection is an alternative on improving plant genetic quality. Prope-legitimate cocoa seeds were obtained from female parents that receive pollen randomly in the same plot of land. The availability of prope-legitimate tolerant seeds can accelerate the efforts to obtain drought-resistant seeds. The tolerance properties estimation of prope-legitimate cocoa seeds in drought stress seeds can be conducted through the identification of the germination character in the osmotic solution (Farooq et al., 2012).

Seed selection required criteria that refer to the germination characters which showed significant interaction variance. Characters with significant interaction of variance indicate that there were the differences in responses between sensitive and tolerant genotypes to stress (Eeuwijk et al., 2016). Based on the 
results of the analysis of variance (Table 1), the character of germination ability, number of sprout leaves, and the sprout fresh weight showed a significant interaction variance. This indicates that these characters can be selected as selection criteria for drought stress tolerance seed.

The tolerance level on plants to drought stress are estimated based on the relative decrease of various growth characters. The relative decrease analysis indicated the level of genotype response to stress condition (De Leon et al., 2015; Anshori et al., 2018b). The analysis results (Table 2) showed that the character of germination ability, number of sprout, leaves and fresh weight of the sprouts decreased varied and that values were reached more than $50 \%$ due to drought stress. Prope-legitimate Sca 06 seeds showed the lowest relative decrease at character of germination ability, the number of sprout leaves, and the sprout fresh weight. The less relative decrease of those characters indicated that the genotype was tolerant to drought stress. Tolerant genotypes are characterized by the ability to survive and growing under stress conditions (Rukundu et al., 2014).

Heritability estimation was analyzed to evalute genetic potential with the phenotypic performance estimation of the selected plants. The inheritance character is important in plant selection (Islam et al., 2015). There are two types of heritability values which consist of broad heritability which define as ratio between genetic variance and phenotypes variance of character $\left(\mathrm{h}_{\mathrm{bs}}^{2}\right)$. The second is the narrow heritability defining as ratio between additives variance and the phenotypes variance $\left(\mathrm{h}_{\mathrm{ns}}^{2}\right)$. The narrow heritability represented the role of additive genes to the phenotypic aspect, so it is often used to determine the selection character (Susilo, 2005; Rubiyo \& Sudarsono, 2011).

Genetic parameters estimation (Table 3) showed that the genetic variance of the germination ability was 11.85 greater than the genetic variance of number of sprout leaves and sprout fresh weight, which were 0.00 and 0.06 . However, the character of germination ability have an individual inheritance value $\left(\mathrm{h}_{\mathrm{ns}}^{2}\right)$ was 0.29 and the average family inheritance $\left(\mathrm{h}_{\mathrm{nsf}}^{2}\right)$ was 0.39 . The individual inheritance value of sprouts fresh weight character was 0.88 and the family inheritance $\left(\mathrm{h}_{\text {nsf }}^{2}\right)$ was 0.99 . Both of the inheritance value on germination ability character in present study was categorized as low level, while the sprout fresh weight was high level (Standfield, 1983). The lower value of narrow heritability on germination ability indicated that the lower effect of additive genetic to the phenotypic expression of germination ability. The phenotype expression of germination character is influenced by genetic factors and environmental condition.

In general, the average family inheritance value $\left(\mathrm{h}_{\text {nsf }}^{2}\right)$ was not different from the individual inheritance value $\left(\mathrm{h}_{\mathrm{ns}}^{2}\right)$, so that the heritability values were effectively used in determining selection criteria. Mean valuebased selection (population) is the most suitable form of family selection for annual plants (Mayo, 1980; Susilo, 2005).

Table 1. Analysis of variance of germination characters of prope-legitimate cocoa seeds to PEG induction

\begin{tabular}{|c|c|c|c|c|c|c|c|c|c|}
\hline Variance source & GA & VI & MGP & NLS & $\mathrm{HL}$ & RL & RHR & SFW & SDW \\
\hline PEG & $0.00^{* *}$ & $0.00^{* *}$ & $0.00^{* *}$ & $0.00^{* *}$ & $0.00^{* *}$ & $0.57^{\mathrm{tn}}$ & $0.00^{* *}$ & $0.00^{* *}$ & $0.00^{* *}$ \\
\hline Genotype & $0.00^{* *}$ & $0.03^{*}$ & $0.19^{\text {tn }}$ & $0.00^{* *}$ & $0.00^{* *}$ & $0.00^{* *}$ & $0.00^{* *}$ & $0.00^{* *}$ & $0.00^{* *}$ \\
\hline PEG x Genotype & $0.00^{* *}$ & $0.13^{\text {tn }}$ & $0.13^{\text {tn }}$ & $0.00^{* *}$ & $0.20^{\operatorname{tn}}$ & $0.09^{\operatorname{tn}}$ & $0.14^{\text {tn }}$ & $0.02 *$ & $0.25^{\mathrm{tn}}$ \\
\hline $\mathrm{CV}(\%)$ & 14.87 & $24.3^{\text {tr1 }}$ & 4.90 & 14.77 & 13.04 & 12.72 & 14.99 & 16.94 & $6.73^{\mathrm{t} 2}$ \\
\hline
\end{tabular}


Table 2. The relative decrease of germination ability, number of leaf sprouts, and sprouts fresh weight of prope-legitimate cocoa seeds to PEG induction

\begin{tabular}{|c|c|c|c|c|c|c|c|c|c|c|c|c|}
\hline \multirow[t]{3}{*}{ Genotype } & \multicolumn{4}{|c|}{ Germination ability(\%) } & \multicolumn{4}{|c|}{ Number of sprout leaves (leaf) } & \multicolumn{4}{|c|}{ Sprout fresh weight $(\mathrm{g})$} \\
\hline & \multicolumn{3}{|c|}{ Environment } & \multirow{2}{*}{$\begin{array}{l}\mathrm{RD} \\
(\%)\end{array}$} & \multicolumn{3}{|c|}{ Environment } & \multirow{2}{*}{$\begin{array}{l}\mathrm{RD} \\
(\%)\end{array}$} & \multicolumn{3}{|c|}{ Environment } & \multirow{2}{*}{$\begin{array}{l}\mathrm{RD} \\
(\%)\end{array}$} \\
\hline & PEG 0\% & PEG 6\% & delta & & PEG 0\% & PEG 6\% & delta & & PEG $0 \%$ & PEG 6\% & delta & \\
\hline KW 516 & 89.6 & 38.4 & 51.2 & 57.1 & 2.92 & 0.97 & 1.95 & 66.9 & 1.59 & 0.80 & 0.79 & 49.9 \\
\hline KW 617 & 84.8 & 56.8 & 28.0 & 33.0 & 2.91 & 1.30 & 1.62 & 55.5 & 1.72 & 0.58 & 1.14 & 66.2 \\
\hline KW 641 & 93.6 & 70.4 & 23.2 & 24.8 & 3.69 & 1.65 & 2.04 & 55.3 & 1.70 & 0.71 & 0.99 & 58.3 \\
\hline ICCRI 03 & 84.0 & 60.0 & 24.0 & 28.6 & 2.73 & 1.19 & 1.54 & 56.3 & 1.29 & 0.66 & 0.63 & 49.1 \\
\hline TSH 858 & 89.6 & 59.2 & 30.4 & 33.9 & 3.28 & 1.26 & 2.02 & 61.5 & 1.82 & 0.76 & 1.06 & 58.2 \\
\hline Sca 06 & 93.6 & 72.8 & 20.8 & 22.2 & 2.70 & 1.81 & 0.89 & 32.9 & 0.99 & 0.60 & 0.39 & 39.5 \\
\hline KEE 02 & 88.0 & 29.3 & 58.7 & 44.6 & 2.62 & 1.12 & 1.50 & 57.2 & 1.08 & 0.48 & 0.60 & 55.3 \\
\hline KKM 22 & 92.0 & 48.0 & 44.0 & 47.8 & 3.34 & 1.25 & 2.10 & 62.7 & 1.53 & 0.66 & 0.88 & 57.2 \\
\hline MCC 02 & 81.6 & 36.0 & 45.6 & 55.9 & 2.86 & 0.83 & 2.02 & 70.9 & 1.92 & 0.76 & 1.16 & 60.5 \\
\hline ICS 60 & 87.2 & 44.4 & 42.8 & 49.1 & 3.01 & 1.09 & 1.93 & 63.9 & 1.67 & 0.75 & 0.93 & 55.3 \\
\hline Sul 01 & 96.0 & 39.2 & 56.8 & 59.2 & 3.19 & 1.30 & 1.89 & 59.2 & 1.62 & 0.73 & 0.89 & 54.8 \\
\hline Sul 02 & 83.2 & 53.6 & 29.6 & 35.6 & 2.84 & 1.35 & 1.49 & 52.4 & 1.39 & 0.68 & 0.71 & 51.2 \\
\hline Sul 03 & 88.8 & 52.8 & 36.0 & 40.5 & 2.79 & 1.33 & 1.46 & 52.4 & 1.36 & 0.54 & 0.82 & 60.2 \\
\hline
\end{tabular}

Table 3. Components of variance, heritability, and deviation standard of genetic variance in prope-legitimate cocoa seed germination to PEG induction

\begin{tabular}{|c|c|c|c|c|c|c|c|}
\hline \multirow{2}{*}{ Characters } & \multicolumn{3}{|c|}{ Variance } & \multicolumn{3}{|c|}{ Heritability } & \multirow{2}{*}{$2^{\sigma_{\sigma_{g}}}$} \\
\hline & $\sigma_{\mathrm{g}}^{2}$ & $\sigma_{\mathrm{i}}^{2}$ & $\sigma_{\mathrm{f}}^{2}$ & $\sigma_{\mathrm{A}}^{2}$ & $h_{n s}^{2}$ & $h_{\text {nsf }}^{2}$ & \\
\hline Germination ability & 11.85 & 164.36 & 130.25 & 47.42 & 0.29 & 0.39 & 67.05 \\
\hline Number of sprout leaves & 0.00 & 0.11 & 0.08 & 0.00 & 0.00 & 0.00 & 0.03 \\
\hline Sprout fresh weight & 0.06 & 0.28 & 0.25 & 0.24 & 0.88 & 0.99 & 0.15 \\
\hline
\end{tabular}

Notes: *Inheritance value that showed more than one was considered the same as one, $\sigma_{\mathrm{E}}^{2}=$ variance of genetic, $\sigma_{i}^{2}=$ variance of individual phenotype, $\sigma_{f}^{2}=$ variance of family phenotype, $\sigma_{\mathrm{A}}^{2}=$ variance of additive, $\mathrm{h}_{\left(\mathrm{ng} \mathrm{s}^{\circ}\right.}^{2}=$ The narrowsense individual heritability, $\mathrm{h}_{\text {(ns } \mathrm{f}_{-}^{\prime-}}^{2}=$ The narrow-sense family heritability, $\sigma_{\sigma_{g}}=$ deviation standard of genetic variance.

Genetic variability describes the genetic background of the genotype tested. The broad and narrow of genetic diversity of a character is determined based on genetic variance $\left(\sigma_{\mathrm{E}}^{2}\right)$ and the standard deviation of genetic diversity $\left(\sigma_{\sigma_{\mathrm{g}}}\right)$. It can be seen that the genetic variance of germination ability and sprout fresh weight was smaller than twice of standard deviation of genetic variances (Table 3 ). Thus, the variability germination ability and sprout fresh weight characters in present study was categorized as narrow. High heritability and wide genetic diversity are important factors in choosing selection criteria. However, the narrow genetic diversity was not directly followed by the narrow phenotypic diversity, because the phenotypic diversity was affected not only by genetic but also environment (Syukur et al., 2011).
Correlation analysis was done to determine the relationship among the observed characters and it was used to obtain selection criteria as carried out by Anita-Sari \& Susilo (2013). The results of the correlation analysis (Table 4) showed that germination has a positive and high correlation with the character of the sprout fresh weight. Positive correlated characters can be used in the selection process as character selection for drought tolerance.

The selection process considered the characters that have wide genetic variability, but character selection should be determined according to the objectives of breeding (Susilo et al., 2005; Devy et al., 2018). Prope-legitimate cocoa seeds that have high germination ability and sprout fresh weight character are considered as tolerant to stress. Thus, they are the most appropriate characters 
Determination of criteria and drought tolerance of prope-legitimate cocoa seeds through polyethylene glycol induction

Tabel 4. Pearson correlation of germination characters of prope-legitimate cocoa seeds to PEG induction

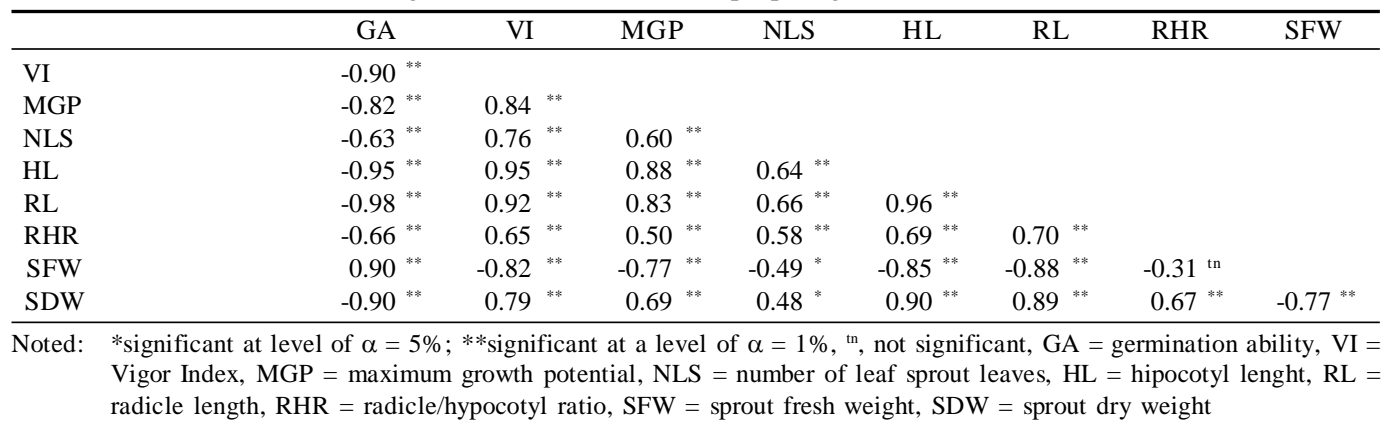

chosen as a selection criteria for prope-legitimate cocoa seeds to drought stress. The estimation of tolerance characteristic of genotypes in the germination phase can be done by using the percentage of germination and sprout weight as a selection criteria (Sumartini et al., 2013; Akbar et al., 2018).

\section{Tolerance Index}

Evaluation of drought tolerance characteristic of genotypes can be predicted using susceptible stress index (SSI). The SSI value is used to measure the yield stability due to changes in the environment related to the mechanism of resistance and genotype susceptibility (Mardeh et al., 2006; Khayatnezhad \& Gholamin, 2012; Anshori et al., 2018b). Genotype selection for drought tolerance was effective if the test is done under optimum and stress conditions.

The results of analysis based on the value of SSI germination ability and sprouts fresh weight (Table 5), showed that the propelegitimate seed genotypes were divided into three groups, namely tolerant, medium tolerant, and susceptible to drought stress. Based on the value of SSI germination ability showed that tolerant seed genotype consisted of Scavina 06; the medium tolerant seed genotypes consisted of KW 641, ICCRI 03, KW 617, TSH 858, Sulawesi 02 and Sulawesi 03; while the susceptible seed genotypes consisted of KEE 02, KKM 22, ICS 60, MCC 02,
Sulawesi 01, and KW 516. Based on the value of SSI sprout fresh weight showed that the seed genotypes were medium tolerant, except the seed genotypes of KW 617, Sulawesi 03, and MCC 02 were susceptible to drought. Genotypes that had a SSI value of $0.5<\mathrm{SSI} \leq 1$ indicated to be medium tolerant, while groups of genotypes that had a SSI value of $>1.00$ were susceptible (Fischer \& Maurer, 1978).

Grouping is done to determine the relationship among plant genotypes. The characteristics of the group of plants need to be known so that the selection process is more effective. One of the method of grouping is clustergram analysis which is a multivariate analysis by combining several cluster analyzes in a flat dimension (Schonlau, 2002). Cluster analysis visualization was simple and easy to understand make this analysis aplicable for selection (Yuan et al., 2016). Color intensity indicates the level of strength or degree of genotype in each character. The differences in color contrast make it easy to determine the characteristics of each genotype group (Lee et al., 2016; Anshori et al., 2018).

Clustergram analysis results showed that the prope-legitimate cocoa genotype dendrogram was divided into three groups (Figure 1). The first group consisted of Sca 06; the second group was divided into subgroup 1 consist of three genotypes, namely ICCRI 03, Sulawesi 02, KW 641, and TSH 858; while subgroup 2 consist of KEE 02, Sulawesi 03, and KW 617. The third group was divided 
Table 5. Tolerance characteristic of prope-legitimate cocoa seeds to PEG induction based on the susceptible stress index of germination ability and sprout fresh weight characters

\begin{tabular}{lclcc}
\hline & \multicolumn{2}{c}{ Germination ability (\%) } & \multicolumn{2}{c}{ Sprout fresh weight (g) } \\
\cline { 2 - 5 } Genotipe & $\begin{array}{c}\text { Susceptible } \\
\text { stress index }\end{array}$ & Criteria & $\begin{array}{c}\text { Susceptible } \\
\text { stress index }\end{array}$ & Criteria \\
\hline Sca 06 & 0.5 & Tolerant & 0.7 & Medium tolerant \\
KW 641 & 0.6 & Medium tolerant & 1.0 & Medium tolerant \\
ICCRI 03 & 0.7 & Medium tolerant & 0.9 & Medium tolerant \\
KW 617 & 0.8 & Medium tolerant & 1.2 & Susceptible \\
TSH 858 & 0.8 & Medium tolerant & 1.0 & Medium tolerant \\
Sulawesi 02 & 0.9 & Medium tolerant & 0.9 & Medium tolerant \\
Sulawesi 03 & 1.0 & Medium tolerant & 1.1 & Susceptible \\
KEE 02 & 1.1 & Susceptible & 1.0 & Medium tolerant \\
KKM 22 & 1.2 & Susceptible & 1.0 & Medium tolerant \\
ICS 60 & 1.2 & Susceptible & 1.0 & Medium tolerant \\
MCC 02 & 1.4 & Susceptible & 1.1 & Susceptible \\
Sulawesi 01 & 1.4 & Susceptible & 1.0 & Medium tolerant \\
KW 516 & 1.4 & Susceptible & 0.9 & Medium tolerant \\
\hline
\end{tabular}

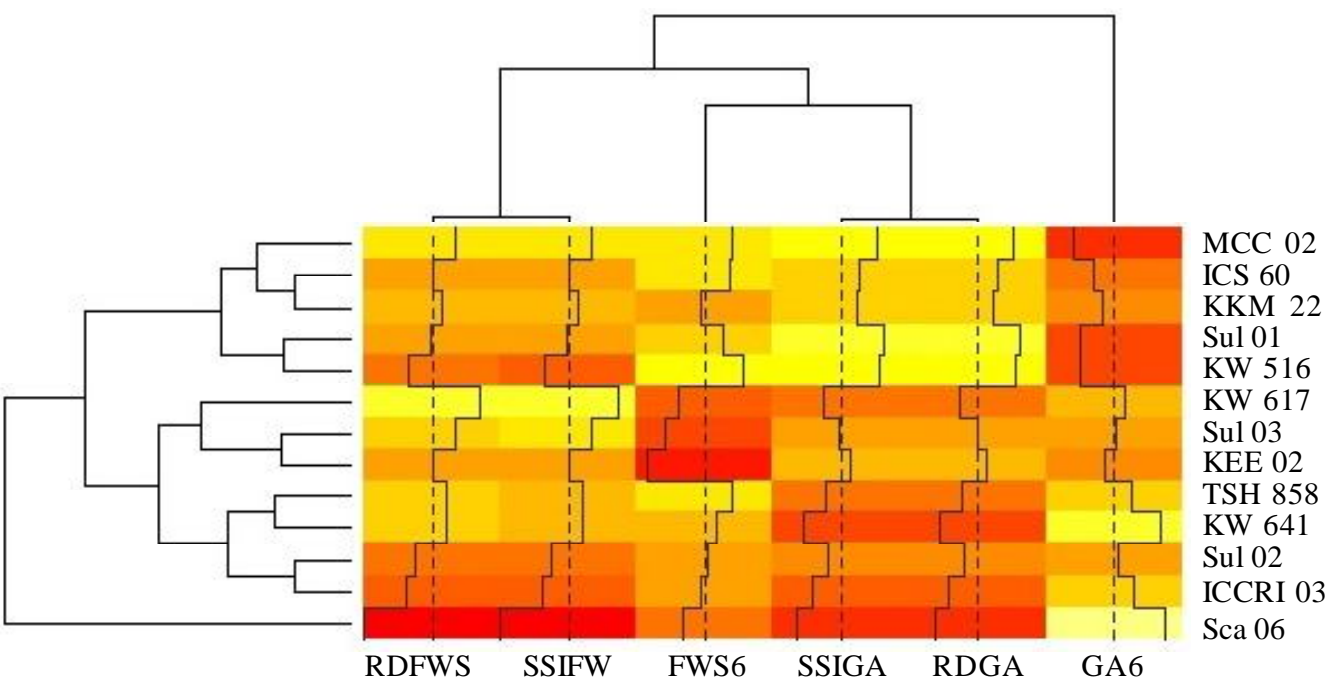

Figure 1. Clustergram heatmap of prope-legitimate cocoa seeds based on 5 observed variables, i.e RDSFW = relative decrease of sprout fresh weight, SSISFW = stress susceptibility index of sprout fresh weight, SFW= sprout fresh weight of PEG induction, SSIGA = stress susceptibility index of germination ability, RDGA = relative decrease of germination ability, GA6 = germination ability of PEG induction

into subgroup 1 consisted of two genotypes, namely KW 516 and Sulawesi 01, while subgroup 2 consisted of KKM 22, ICS 60, and MCC 02. This grouping was based on the pattern of color intensity on the germination characters supported by the value of stress susceptibility index. The relationship between genotypes was explained by a dendogram that divide groups into each subgroup.
The first and second group were groups that were indicated to be tolerant prope-legitimate seed genotypes. The third group was indicated to be susceptible propelegitimate seed genotypes. In general, the tolerant seed genotype group have a high germination ability and a low of the relatively decrease on germination ability. The prope-legitimate seed genotypes of Sca 06 
showed the highest degree of tolerance in the group. The sensitive genotypes have a low germination ability and a high of the relatively decrease on germination ability. The relative decrease of sprout fresh weight in all prope-legitimate seed genotypes were various and can be predicted not different.

PEG induction in germination media shows its role in suppressing water imbibition which causes number of seeds to germinate was low. The effect of PEG on the decrease in germination was also reported by Lahay et al. (2018) that the decrease in water content due to PEG induction correlates with the level of viability of recalcitrant cocoa seeds. Sufficient water in the growing environment requires cocoa seeds to soften the seed coat, dissolve food reserves, and hormone activity (Yuliasmara, 2015). Diversity of the character of prope-legitimate seed germination against drought is influenced by genotypes related to seed quality (viability and vigor) and environmental conditions of germination.

\section{CONCLUSION}

Germination ability was the most appropriate selection criterion for determining the tolerance properties of prope-legitimate seeds in drought to PEG induction. The group for tolerant genotype was Sca 06, while the group for medium tolerant consisted of ICCRI 03, Sulawesi 02, KW 641, TSH 858, KEE 02, Sulawesi 03, and KW 617. The susceptible group consisted of five genotypes, namely KW 516, Sulawesi 01, KKM 22 , ICS 60, and MCC 02.

\section{ACKNOWLEDGMENT}

We wish thank you to the Indonesian Ministry of Research, Technology and Higher Education for providing funding to carry out this research through the Domestic
Postgraduate Scholarship Program. We also wish thank you to the Indonesian Coffee and Cocoa Research Institute, Jember, Indonesia, which facilitated the research.

\section{REFERENCES}

Akbar, M.R.; B.S Purwoko; I.S. Dewi \& W.B. Suwarno (2018). Penentuan indeks seleksi toleransi kekeringan galur dihaploid padi sawah tadah hujan pada fase perkecambahan. Jurnal Agronomi Indonesia, 46, 133-139.

Alban, M.K.A.; S.E. Apshara; T.G. Mathias \& A. Severin (2015). Potential of antiokxidant enzymes in depicting drought tolerance in cocoa (Theobroma cacao L.) genotypes at young age. African Journal of Science and Research, 4, 18-23.

Amos, T.T. \& T.O. Thompson (2015). Climate change and the cocoa production in the tropical rain forest ecological zone of Ondo State, Nigeria. Journal of Environment and Earth Science, 5, 36-41.

Anderson, R.L. \& T.A. Bancroft (1952). Statistical Theory in Research. Mc Graw Hill Book Company, New York, USA. 399 p.

Anita-Sari, I. \& A.W. Susilo (2013). Pengembangan kriteria seleksi karakter berat biji pada tanaman kakao (Theobroma cacao L.) melalui pendekatan analisis sidik lintas. Pelita Perkebunan, 29, 174-181.

Anshori, M.F.; B.S. Purwoko; I.S. Dewi; S.W. Ardie; W.B. Suwarno \& H. Safitri (2018b). Determination of selection criteria for screening of rice genotypes for salinity tolerance. SABRAO Journal of Breeding and Genetics, 50, 279-294.

Anshori, M.F.; B.S. Purwoko; S.W. Ardie; W.B. Suwarno \& H. Safitri (2018). Heritabilitas, karakterisasi, dan analisis clustergram galur-galur padi dihaploid hasil kultur antera. Jurnal Agronomi Indonesia, 46, 119-125.

Baloch, M.J.; J. Dunwell; A.Z. Khakwani; M. Dennet; W.A. Jatoi \& S.A. Channa 
(2012). Assessment of wheat cultivars for drought tolerance via osmotic stress imposed at early seedling growth stages. Journal Agricultural Research, 50, 299-310.

Boopathi, N.M.; G. Swapnashri; P. Kavitha; S. Sathish; R. Nithya; W. Ratnam \& A. Kumar (2013). Evaluation and bulked segregant analysis of major yield QTL 12.1 intogressed into indigenous elite line for low water availability under water stress. Rice Science, 20, 25-30.

Cazares, B.X.; F.F. Elenes \& R.R. Medrano (2010). Drought tolerance in crop plants. American Journal of Plant Physiology, 5, 241-256.

De Almeida; J.W. Tezara \& A. Herrera (2016). Physiological responses to drought and experimental water deûcit and waterlogging of four clones of cacao (Theobroma cacao L.) selected for cultivation in Venezuela. Agricultural Water Management, 171, 80-88.

De Leon, TB; S. Linscombe; G. Gregorio \& P.K. Subudhi (2015). Genetic variation in southern USA rice genotypes for Seeding Salinity Tolerance. Frontier in Plant Science, 8, 1-13.

Devy, L.; I. Anita-sari; A.W. Susilo; A. Wachjar \& Sobir (2018). Genetic diversity and indirect selection of fine cacao (Theobroma cacao) based on bean color. Biodiversitas, 19, 2385-2392.

Dos Santos, E.A.; A.A.F. de Almeida; D. Ahnert; M.C. da Silva Branco; R.R. Valle \& V.C. Baligar (2016). Diallel analysis and growth parameters as selection tools for drought tolerance in young Theobroma cacao plants. PLOS ONE, 11, 1-22.

Eeuwijk, F.A.V.; D.V. Bustos-Korts \& M. Malosetti (2016). What should students in plant breeding know about the statistical aspects of genotype environment interactions. Crop Science, 56, 2119-2140.

Farooq, M.; M. Hussain; A. Wahid \& K.H.M. Siddique (2012). Drought stress in plants an overview. p. 1-33. In: Plant Responses \& Drought from
Morpological to Moleculer Features. ( R. Aroca, Ed.). Springer Heidelberg New York Dordrecht London.

Fischer, R.A. \& R. Maurer (1978). Drought resistance in spring wheat cultivars. I. Grain yield response. Aust. Journal Agric. Res, 29,897-907.

Gateau-Rey, L.; E.V.J. Tanner; B.J-P. Marelli \& S. Royaert (2018). Climate change could threaten cocoa production: Effects of 2015-16 El Nino-related drought on cocoa agroforests in Bahia, Brazil. PLOS ONE, 13, 1-17.

George, S.; S.A. Jatoi \& S.U. Siddiqui (2013). Genotypic differences against PEG simulated drought stress in tomato. Pakistan Journal Botany, 45, 1551-1556.

Hutabarat, S.L.; Haryati \& Irsal (2018). Pengaruh jenis larutan osmotik pada invigorasi benih kakao (Theobroma cacao L.) dengan beberapa lama pengeringan. Jurnal Pertanian Tropik, 5 (1:17), $128-135$.

Islam, M.A.; S.A. Raffi; M.A. Hossain \& A.K. Hasan (2015). Analysis of genetic variability, heritability, and genetic advance for yield and yield associated traits in some promising advanced lines of rice. Progressive Agriculture, $26,26-31$.

Khayatnezhad, M. \& R. Gholamin (2012). The effect of drought stress on leaf chlorophyll content and stress resistance in maize cultivars (Zea mays). African Journal of Microbiology Research, 6, 2844-2848.

Khodarahmpour, Z. (2011). Effect of drought stress induced by polyethylene glycol (PEG) on germination indices in corn (Zea mays L.) hybrids. African Journal of Biotechnology, 10, 18222-18227.

Lahay, R.R.; S. Misrun \& R. Sipayung (2018). The storage capacity of cocoa seeds (Theobroma cacao L.) through giving polyethylene glycol (PEG) in the various of storage container. International Conference on Agriculture, Environment, and Food Security. pp. 122, 012040. 
IOP Publishing IOP Conf. Series: Earth and Environmental Science.

Lee, J.E.; M. Recker; A.J. Bowers \& M. Yuan (2016). Hierarchical cluster analysis heatmaps and pattern analysis: an approach for visualizing learning management system intercation data to proceeding. Proceeding of the $9^{\text {th }}$ International Conference on Educational Data Mining. North Corolina.

Mardeh, S-S.; A. Ahmadi; K. Poustini \& V. Mohammadi (2006). Evaluation of drought resistance indices under various environmental conditions. Field Crops Research, 98, 222-229.

Mayo, O. (1980). The Theory of Plant Breeding. Oxford University Press. New York.

Mexal, J.; J.T. Fisher; J. Osteryoung \& C.P.P. Reid (1975). Oxygen availability in polyethylene glycol solutions and its implications in plant-water relations. Plant Physiology, $55,20-24$.

Michel, B.E. \& M. Kaufmann (1973). The osmotic potential of polyethylene glycol 6000. Plant Physiology, 51, 914-916.

Mirbahar, A.A.; R. Saeed \& G.S. Markhand (2013). Effect of polyethylene glycol6000 on wheat (Triticum aestivum L.) seed germination. International Journal of Biology and Biotechnology, 10, 401-405.

Muscolo, A.; M. Sidari; U. Anastasi; C. Santonoceto \& A. Maggio (2014). Effect of PEGinduced drought stress on seed germination of four lentil genotypes. Journal of Plant Interactions, 9, 354-362.

Ofori, A.; F.K. Padi; K. Acheanpong \& S. Lowor (2015). Genetic variation and relationship of traits related to drought tolerance in cocoa (Theobroma cacao L.) under shade and no-shade conditions in Ghana. Euphytica, 201, 411-421.

Petrovit; G.D. Jovicic; Z. Nikolic; G. Tamindzic; M. Idnjatov; D. Milosevic \& B. Milosevic (2016). Comparative study of drought and salt stress effect on germination and seedling growth of pea. Genetika, 48, 373-381.
Rahardjo, P. (1986). Penggunaan polyethylene glycol (PEG) sebagai medium penyimpanan benih kakao (Theobroma cacao L.). Pelita Perkebunan, 2, $103-108$.

Rahayu, A.; T. Hardiyati \& P. Hidayat (2014). Pengaruh Polyethylene Glycol 6000 dan lama penyimpanan terhadap mutu benih kakao (Theobroma Cacao L.). Pelita Perkebunan, 30, 15-24.

Rubiyo \& Sudarsono (2011). Pendugaan parameter genetik ketahanan tanaman kakao terhadap penyakit busuk buah. Buletin RISTRI, 2, 391-404.

Rukundu, P.; H.G. Betaw; S. Ngailo \& F. Balcha (2014). Assessment of drought stress tolerance in root and tuber crops. Review. African Journal of Plants Science, 8, 214-224.

Schonlau, M. (2002). The clustergram: A graph for visualizing hierarchical and nonhierarchical cluster analyses. The Stata Journal, 2, 391-402.

Setyawan, B; N. Puspitasari; A.W. Susilo \& I. Anita-Sari (2018). Rootstock characteristics of three combinations of Theobroma cacao L. crosses on different water availability. Pelita Perkebunan, 34, 137-145.

Sevik, H. \& N. Erturk (2015). Effects of drought stress on germination in fourteen provenances of Pinus brutia Ten. seeds in Turkey. Turkish Journal of Agriculture-Food Science and Technology, 3, 294-299.

Shao, R.X.; L.F. Xin; H.F. Zheng; L.L. Li; W.L. Ran; J. Mao \& Q.H. Yang (2016). Changes in chloroplast ultrastructure in leaves of drought-stressed maize inbred lines. Photosynthetica, 54, 74-80.

Singh, R.K. \& B.D. Chaudhary (1979). Biometrical Methods in Quantitatif Genetics Analysis. Kalyani Pub. Ludhiana. New Delhi.

Stansfield, W.D. (1983). Theory and Problem in Genetics Schaum's Outlines Series. McGraw Hill Book. Co.

Sumartini, S.; E. Sulistyowati; S. Mulyani \& Abdurrakhman (2013). Skrining galur 
kapas (Gossypium hirsutum L.) toleran terhadap kekeringan dengan PEG-600 pada Fase Perkecambahan. Jurnal Littri, 19, 139-146.

Susilo, A.W. (2015). Bahan Tanam Kakao. p. 79-93. In: Kakao Sejarah, Botani, Proses Produksi, Pengolahan, Perdagangan. T. Wahyudi, Pujiyanto \& Misnawi (Eds). Pusat Penelitian Kopi dan Kakao Indonesia. Gadjah Mada University Press.

Susilo, A.W.; D. Sulastri \& S. Djatiwaloejo (2005). Seleksi dan pendugaan parameter genetik beberapa sifat batang bawah kakao (Theobroma cacao L.) pada semaian famili saudara tiri. Pelita Perkebunan, 21, 147-158.

Syukur, M.; S. Sujiprihati; R. Yunianti \& D.A. Kusumah (2011). Pendugaan ragam genetik dan heritabilitas karakter komponen hasil beberapa genotipe cabai. Agrivigor, 10, 148-156.

Warschefsky, E.J.; L.L. Klein; M.H. Frank; D.H. Chitwood; J.P. Londo; E.J.B. von Wettberg \& A.J. Miller (2016). Rootstocks: Diversity, domestication, and impacts on shoot phenotypes. Trends in Plant Science, 21, 418-437.

Widyastuti, Y.; B.S. Purwoko \& M. Yunus (2016). Identifikasi toleransi kekeringan tetua padi hibrida pada fase perkecambahan menggunakan polietilen glikol (PEG) 6000. Jurnal Agronomi Indonesia, 44, 235-241.

Yuan, J.; A. Murphy; D.D. Koeyer; M. Lague \& B. Bizimungu (2016). Effectiveness of the field selection parameters on potato yield in Atlantic Canada. Canadian Journal of Plant Science, 96, 701-710.

Yuliasmara, F. (2015). Manajemen pembibitan tanaman kakao. p. 171-202. In: Kakao Sejarah, Botani, Proses Produksi, Pengolahan, Perdagangan. T. Wahyudi, Pujiyanto \& Misnawi (Eds). Pusat Penelitian Kopi dan Kakao Indonesia. Gadjah Mada University Press.

Zakariyya, F. \& D. Indradewa (2018). Drought stress affecting growth and some physiological characters of three cocoa clones at seedling phase. Pelita Perkebunan, 34, 156-165. 